\section{A POSSIBLE RECENT RECORD OF THE BARN OWL IN SASKATCHEWAN}

by Glen A. Fox, Kindersley

The Barn Owl (Tyto alba) is only of casual occurrence in Saskatchewan (A.O.U., 1957). It is therefore of interest to record the following information. On May 18, 1960, I found the carcass of an owl, which I identified as this species, a few hundred yards from an occupied farm site, one mile south of Kindersley. It had undergone considerable decomposition but the white, heartshaped "monkey face," and the long, unfeathered tarsi were still very noticeable. The plumage appeared to be very light with rusty markings. This data was recorded as part of my study of the birds of the Kindersley area. Unfortunately, as I was unaware of the significance of the discovery, the carcass was not preserved for confirmation of the identification, hence this should only be regarded as a hypothetical record.

There are apparently only two other records of this species in the province. William Pound is credited with collecting a specimen on May 5 , 1924, at Aylesbury (west of Last Mountain Lake); the mounted specimen is on display in the Saskatchewan Museum of Natural History. The A.O.U. Check-list (1957) and A. C. Bent (1938) both refer to this specimen as the only one for the province. However, George Lang (Mitchell, 1924) mentions another: "I saw this bird on April 29, 1910, on the Experimental Farm (Indian Head); two days later a man brought a fine male in from Balcarres, which I am almost sure was my bird, and Harvey mounted it for him."

This species has been recorded only rarely in Western Canada and the adjacent States. There are no records listed in the Birds of Alberta (1958), and it is therefore of interest to note that the possible recent record described herein is for a location only 40 miles from the Alberta border. It is also the first record for Saskatchewan in almost 40 years.

\section{LITERATURE CITED}

American Ornithologists' Union, 1957. Checklist of North American birds. 5th Edition. Baltimore.

Bent, Arthur Cleveland. 1938. Life histories of North American birds of prey, Pt. 2. U.S. Nat. Museum Bull. 170. Washington, D.C.
Mitchell, H. Hedley. 1924. Catalogue of birds of Saskatchewan. Can. Field-Nat. 38:101118.

Salt, $\dot{W}_{\text {. }}$ Ray and A. L. Wilk. 1958. The birds of Alberta. Edmonton, The Queen's Printer.

\section{NOTES ON A BURROWING OWL NEST}

by Mrs. E. Boon, Tullis

A recent report of Burrowing Ow!s still living in burrows on September 9, 1962, at Regina (Audubon Field Notes, 17:43) interested me inasmuch as we had some still in burrows to October 14 in the same year. A pair nested in an old badger hole in a coulee about one-half mile from our buildings. As the nest site was close to our field road we saw them nearly every day. My earliest observation was made on April 26 when one owl was seen sitting near the badger hole. On April 30 there were two owls at the nest site, the second bird being considerably lighter in color than the first. Some two weeks later, on May 17, I noted that there was straw all around the hole and I found a dead field mouse in the opening. From this time on, I noticed dead mice around and in the hole every day, sometimes as many as six at one time (May 24). Occasionally during this period we saw one and sometimes both owls at a time. On July 23 two young owls emerged from the hole, and by Aug. ust 31 , there were actually 14 young owls at the nest site. These 14 young and their parents were still present around the hole on September 6, but from this time on they gradually left, a few at a time. On October 14 I found one owl still remaining, and it was gone when I checked the next day.

I presume Burrowing Owls begin to incubate as soon as the first egg is laid, as most owls do, but 14 seemed like an awfully big family to me However, there they were. By September they were very pretty, shiny and rust-coloured against the dead grass. They seemed to be slow in developing the ability to fly; they were only making short flights, and mostly just sitting around on September 6 .

Ed. Note: Peterson (1961. A field guide to western birds) gives figures of five to nine eggs as an average, with a record of 12 in one clutch. If these 14 young birds belonged to one family, the clutch recorded above may therefore be a new record for this species. Tullis is west of Elbow in southwestern Saskatchewan. 